UDC 339.9

DOI 10.33111/iep.eng.2021.34.01

\title{
Global trends in the social economy development
}

\section{NataliIa Stukalo ${ }^{1}$, AnASTASIIA SimakHOVA ${ }^{2}$}

\begin{abstract}
The article analyses traditional and newest global trends in the social economy development, including in particular, transnationalization, regionalization, institutionalization, digitalization, intellectualization, innovation, technologization, inclusiveness, greening of the economy. It has been established that global trends in informatization, intellectualization, innovation and digitalization are quite interrelated and interdependent. The social economy serves to meet social needs, as well as help realize the individual potential of each person. The research of global trends in the social economy makes it possible to analyse in a holistic way the trajectory of the social economy models' development, as well as to use in practice the potential of global trends to enhance the social component of the economic development of countries in the global dimension. The intensification of integration processes, regional and interregional transformations lead to changes in the national economy structure and shifts in socialization processes at the macro- and meso-level followed by different practical results and impact on the social economy development of the countries all over the world. A scientific and technological progress, Industries 4.0 and 5.0 development, the creation of smart enterprises and cities, digital transformations affect the socialization of the economy in a global environment. The article critically evaluates the positive and negative impacts of the latest global trends on the socialization of the economies of the countries all over the world. The latest trends in pandemic development will affect the provision of national and global competitiveness, the development of small business, the functioning of the capital market, the quality of life, employment of the population and its forms, the medical sphere and the education system, as well as socialization processes. There are considered the signs of postpandemic development of the world community, that enhances both global opportunities and dangers. There are proposed the directions of strengthening the positive effect of global development trends on the social economy.
\end{abstract}

KEYWORDS: globalization, social economy, global trends, transnationalization, regionalization, institutionalization, digitalization, intellectualization, greening, socialization, post-pandemic development.

\section{Introduction}

The development of the social economy in the global space is becoming increasingly important. Ensuring the well-being of the population, stability, high-quality development of education, medicine, security, the social economy fulfils its tasks and meets the requirements and challenges

* This article was translated from its original in Ukrainian.

${ }^{1}$ Stukalo Nataliia Vadymivna - Doctor of Economics, Professor, Deputy Chairman of the The National Agency for Higher Education Ouality Assurance. Sphere of scientific interest: quality assurance in higher education, sustainable development, financial globalization, international business. E-mail: nstukalo@ naqa.gov.ua

${ }^{2}$ Simakhova Anastasiia Oleksiivna - Doctor of Economics, Associate Professor, Associate Professor of the Department of International Economics of the National Aviation University. Sphere of scientific interest: social economy, socialization, global development, innovation and investment factors, scientific potential. E-mail: anastasiia.simakhova@npp.nau.edu.ua

IEP, No. 34 (2021), pp. 7-22

(C) Nataliia Stukalo, Anastasiia Simakhova, 2021 «All rights reserved»

ISSN 1811-9832/2021/No. 1 (34) 
of the times. Moreover, in the social economy, emphasis is placed on the individual with its various needs and capabilities, to satisfy and realize which ones, the effective socialization of the economy is called upon.

Of course, the development of the social economy in the global dimension is influenced by various trends, in particular, transnationalization, regionalization, institutionalization, digitalization, intellectualization, innovation, technologization, inclusiveness, greening of the economy. In the context of the COVID-19 pandemic, the study of signs of post-pandemic development of the world community is of particular importance. The outlined above determines the relevance and importance of the research topic.

Many Ukrainian scientists were engaged in researching global development trends, who studied the essence and effects of their influence on national economies. Among the main studies, it should be noted the scientific works of such scientists as D.H. Lukianenko, A.M. Poruchnyk, A.M. Kolot, Ya.M. Stoliarchuk ${ }^{3}$ and others, who examined the trends of informatization, innovation, technologization, regionalization and institutionalization of the global economy and its social component.

Scientists A. Kolot. O. Herasymenko ${ }^{4}$, I. Kaleniuk, A. Diakon ${ }^{5}$, V. Menshykov ${ }^{6}$ and others researched the trend of digitalization of the economy and its impact on social development. Despite the significant achievements of domestic and foreign scientists in the study of global development trends, the issue of their influence on the social economy development, both positive and negative, is still studied, which determined the importance hereof.

The purpose of this article is to study the signs of global trends in the development of the social economy, highlighting the prospects for their positive impact on the socialization of the economies of the countries all over the world.

\section{Global trends in the socio-economic development}

The main trends in the social economy development at the global level are the following: transnationalization; regionalization; institutionalization;

\footnotetext{
${ }^{3}$ Resources and models of global economic development (ukr. Resursy ta modeli hlobalnoho ekonomichnoho rozvytku): monohrafiia, za zah. red. Lukianenka D.H., Poruchnyka A.M. K.: KNEU, 2011. 703 s. [In Ukrainian]

${ }^{4}$ Kolot A., Herasymenko O. Digital transformation and new business models as determinants of formation of the economy of nontypical employment. Social and labour relations: theory and practice, 2020, 10(1), 33-54. doi:10.21511/slrtp.10(1).2020.06

${ }^{5}$ Kalenvuk I., Dvakon A. Modern trends in the development of education in a global context; Strategic priorities for developing Ukraine and Georgia: innovation and partnership: [monograph] / under ed. D. G.Lukianenko and T. Beridze. Batumi, 2018. 308 p. (P. 224-244)

${ }^{6}$ Menshikov V., Lavrinenko O., Sinica L., Simakhova A. Network capital phenomenon and its posibilities under the influence of development of information and communication technologies, Journal of Security and Sustainability Issues 2017, 6(4), 585-604 doi: http://doi.org/10.9770/jssi.2017.6.4.(5).
} 
greening; digitalization, informatization, intellectualization; innovation; technologization; inclusiveness.

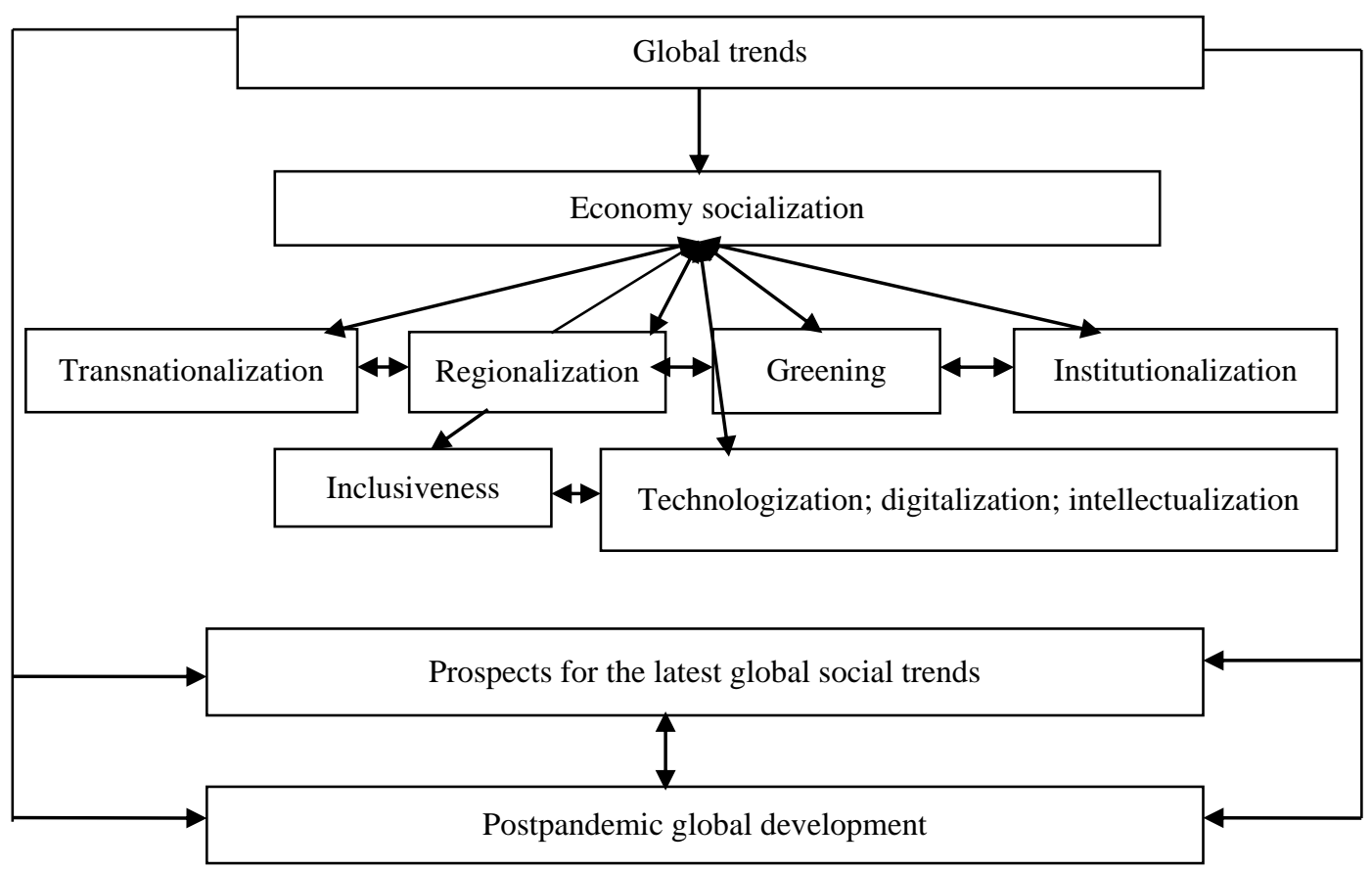

Fig. 1. Global trends in the social economy

Source: developed by the authors.

Global trends shown in Fig. 1. contain both traditional trends for the world economy and the latest trends in greening, digitalization, and inclusiveness. This makes it possible to analyse the trajectory of the social economy development comprehensively, as well as to use in practice the potential of global trends to enhance the social component of the economic development of countries in the global dimension.

The transnationalization of the global economy as a trend of world integration due to the actions of global actors (TNCs, influential media) affects the development of the social economy. There is no doubt that the TNCs activities, in addition to economic consequences, have a certain social effect on the social economy development. The transnationalization as a modern development trend affects labour productivity, employment of the population, income level, welfare, social status of workers, the formation of social values and corporate social culture, as well as the political and social 
environment, often creating a certain political lobby of certain government decisions. TNCs also influence investment policies in countries, contribute to increased competitiveness and innovative, digital and information development ${ }^{7}$.

TNCs implement social projects, develop social infrastructure. The transnationalization is associated with such global imperatives as: «formation of a global market, global monopolization of capital and production», regionalization and informatization of the global space ${ }^{8}$. At the same time, the transnationalization is associated with modern trends in the intellectualization and innovation of the global economy.

Global regionalization affects the development of the social economy of certain regional groupings. The regionalization of the economy socialization has its demonstration both at the macro-, meso- and at the global level. At the same time, regional models of the social economy are grouped according to certain characteristic and specific features, patterns of development (for example, the Scandinavian model, the Mediterranean model, etc.). The intensification of integration processes, regional and interregional transformations lead to changes in the structure of the national economy and shifts in socialization processes at the macro- and meso-level, which in turn has a different practical result and impact on the model of the social economy. The transformation of the social and economic development of regions as a component of the global trend of regionalization is reflected in the social development of countries and calls for the development and implementation of effective regional strategies for social development, taking into account the process of socialization at the meso- and global levels.

At the meso-level, its own social space is created, as well as regional social cooperation, the creation of regional social institutions, the development of regional social norms, rules, standards, affects the effectiveness and efficiency of the social economy ${ }^{9}$.

The regionalization affects decentralization, the formation of a general social policy of the region, communications between different social groups, regional social values and culture. The influence of this global trend on the integration of countries, strengthening of social ties between various groups of people, regional social programs and projects, as well as the innovation and informatization of public relations is important.

\footnotetext{
${ }^{7}$ Simakhova A. O. Models of social economy in the global dimension $(u k r$. Modeli sotsialnoi ekonomiky u hlobalnomu vymiri): dys.. ... doktora ekonomichnykh nauk : spets. 08.00.02. - K.: 2020, 473 s. [In Ukrainian].

${ }^{8}$ Poruchnyk A. M. Stoliarchuk Ya.M. Global imperatives of transnationalization of national economies ( $u k r$ Hlobalni imperatyvy transnatsionalizatsii natsionalnykh ekonomik). Formuvannia rynkovoi ekonomiky : zb. nauk. pr. Kyiv : KNEU, 2009. Vyp. 21. 257-278. - S. 257. [In Ukrainian].

${ }_{9}$ Simakhova A. O. Models of social economy in the global dimension (ukr. Modeli sotsialnoi ekonomiky u hlobalnomu vymiri): dys.. ... doktora ekonomichnykh nauk : spets. 08.00.02. - K.: 2020, 473 s. [In Ukrainian].
} 
The global institutionalization is showed in the formation of a system of institutions that ensure the effectiveness of the social economy model and an effective form of interaction between all global actors. Institutionalization, at the global level, is a trend of consolidating global social rules, norms, standards to ensure the well-being of the population in the countries of the world, along with the functioning of certain social institutions. Global institutions provide international social cooperation, if necessary, help developing countries to overcome and minimize the consequences of global problems and challenges of humanity.

The effectiveness of the social economy depends on the effective involvement of all potential social and economic institutions for the implementation of social goals. In addition, social development requires the coordination of actions and strategies of these institutions, together with the persistent efforts of the banking and financial sector to strengthen the source base of socialization of the economies of the countries of the world. The banking sector in this perspective has the potential to address the issue of decentralized distribution of financial resources for social purposes. Commercial and foreign banks in most of the developed social countries of the world act as those social institutions that directly or indirectly satisfy various consumer and production needs. The banking sector creates conditions for improvement of the well-being of people, for opportunities to choose various directions to improve conditions and quality of life, in particular through the credit system. This experience of involving the banking sector in the economy socialization processes is important for countries with transitional economies and developing countries.

It is worth noting that in addition to the main global trends in the development of social economy models, such new global trends as the inclusiveness of the social economy, informatization, intellectualization, innovation, digitalization and greening (development of a "green" economy, "green" technologies) have become more and more relevant.

Inclusiveness as the latest trend in the social economy model development reflects the diversity and multidimensionality of its factors. The development of the social economy at the global level is determined not only by the well-being and high standard of the population living, but also by other components: the education system, health care, environmental component, and security. The social economy at the present stage should positively influence as many people as possible, ensuring their decent standard of living. Moreover, there should be equality of all groups of the population before social benefits, despite a certain identity or belonging, without social stratification, as well as employment, salaries, career growth, etc. The inclusiveness is associated with the intellectual and human capital development, with the trend of the world economy 
intellectualization, when investment in intellectual capital is an important factor $^{10}$.

\section{Global economy intellectualization and digitalization}

Informatization, intellectualization, innovatization and digitalization as modern global development trends are quite interconnected. Thus, the informatization of society leads to the comprehensive use of information technologies, networking, platformization, the rapid dissemination of new knowledge, formation of new skills among people. In turn, this affects the intellectualization, innovation and digitalization of the economy. There is a rapid spread of technology and the commercialization of knowledge.

The intellectualization of the global economy leads to an increase in the value of intellectual capital, to the need for constant professional growth and human development, which is associated with the development of the social sphere and social economy. TNCs, international organizations, companies and enterprises take an active position in the international labour market in the search and employment of highly qualified personnel, specialists, since it is the intellectual potential of companies that becomes the determinant of the economic growth of enterprises.

There's no question, that the economy intellectualization is becoming the main driving force behind the development of national economies, the competitiveness of the country, TNCs, enterprises, organizations and companies, and is also the basis for its innovation and subsequent digitalization. The development of Industry 4.0 with the growing influence of digitalization and artificial intelligence technology is leading to the transformation of the entire system of public relations. A global innovative and intelligent space is being created.

The digitalization of society is the latest trend in the social economy development. In general, digital transformation, like global trends in innovation and intellectualization, play a key role in modernization of the economy at all levels, and is reflected in the development of the social sphere. There is no doubt that the economy digitalization on the social sphere of countries has its influence through the population employment (non-traditional forms of employment, new professions), the health care system (treatment of fatal diseases, increasing life expectancy), the standard of living of the population (incomes, salaries) and the quality of population life (expanding the range of goods, the ability to order goods

\footnotetext{
${ }^{10}$ Simakhova A. O. Models of social economy in the global dimension ( $u k r$. Modeli sotsialnoi ekonomiky u hlobalnomu vymiri): dys.. ... doktora ekonomichnykh nauk : spets. 08.00.02. - K.: 2020, 473 s. [In Ukrainian].
} 
via the Internet) ${ }^{11}$. An artificial intelligence creates new opportunities for quickly solving complex problems, simplifying human labour activity, but at the same time leads to massive layoffs from industries that have begun to use robots. Another negative aspect of the impact of the digitalization of the economy on the social sphere is changes in the regional structure of the distribution of production factors.

Digital trends affect all spheres of life and already today have both positive and negative effects on the social economy development. Thus, the weak implementation of the economy socialization leads to an increase in the social and economic inequality of the population, when the main catalyst for this negative process can be, together with economic inequality, other factors in the context of the development of Industry 4.0 with the growing influence of digitalization and artificial intelligence technology.

It is worth mentioning that, in general, digitalization, despite the negative aspects of its functioning, contributes to the expansion of consumption and an improvement in the quality of the population life. The development of the e-government system has also a positive effect on the social economy, by simplifying the access of the population to the authorities and by requesting public information from them. Due to the active development of social networks, the digitalization of the economy influences the social sphere, the values and culture of society ${ }^{12}$, the mentality and consciousness.

Block chain technology is also promising for the social economy development in a global context, which in the future may allow solving many issues from different spheres of life - from the economy to the healthcare sector. Since the use of block chain technology is not limited to the only financial sector, it can be used to record, track, monitor and carry out transactions with any assets, as well as in the field of public and corporate governance.

The newest trend of technologization is reflected in the qualitative transformation of intellectual capital and intellectual property, the structure of the labour market and social guarantees of forced unemployment, the system of vocational education throughout life. Artificial intelligence-based technology accelerates all social and economic processes. Being the latest development trend, technologization is associated with such trends as the digitalization of the economy, innovation, informatization, intellectualization, the development of block

\footnotetext{
${ }^{11}$ Simakhova A. O. Social prospects for the development of science and digital economy in Ukraine (ukr. Sotsialni perspektyvy rozvytku nauky ta tsyfrovoi ekonomiky v Ukraini), Sotsialna ekonomika, 2018. Vyp. 56.

S. $216-221$. [In Ukrainian].
${ }_{12}$ Ibid.
} 
chain technologies, the high-tech sector, and the IT sphere, which is attracting more and more countries of the world community.

The scientific and technological progress, the development of Industries 4.0 and 5.0, the creation of smart enterprises and cities, digital transformations affect the connection between technology and the economy, as a result - there is a social division of labour, the development of productive forces, an increase in labour productivity, specialization, cooperation and international cooperation. There's no question, this affects the socialization of the economy. The socialization of scientific and technical activity, together with the socialization of the productive forces, ensure the interaction between the worker and the means of labour, including artificial intelligence, etc.

The Information Society Index and the Network Readiness Index are used to assess shifts in the digitalization and informatization of the economy. The Information Society Index is an indicator that actually sets the standard for measuring the capabilities of a particular country in accessing and using information and information technologies. With the aim to calculate this index, 23 variables are used, which are divided into 4 groups ${ }^{13}$. Thus, countries are divided into the following groups: "Skaters" (countries with strong positions regarding the use of an information technology); "Striders" (countries that successfully develop information technologies); "Sprinters" (countries that are unevenly moving towards an information society for a number of factors); "Strollers" (countries that are slowly moving towards an information society through social and economic problems). According to statistics, ICT services are more accessible throughout the world, not only in developed countries, but also in developing countries. Countries such as China, Kuwait, United Arab Emirates, Croatia, Norway, Brunei, Iran and Luxembourg have the first positions in this indicator. That is to say, developed countries and developing countries. The last positions in this list are occupied by Burundi, Madagascar, Niger, Rwanda, Malawi, Haiti, Guinea-Bissau, Uganda and Togo, developing countries ${ }^{14}$.

The Network Readiness Index is a comprehensive indicator that measures the level of development of information technologies by various parameters, which are grouped into the following main groups: the availability of conditions for development, the willingness of citizens, businesses and government bodies to use information technologies, the direct level of use of technologies in various sectors, as well as their impact. In 2020, this index was calculated for 134 countries, representing $98 \%$ of global GDP ${ }^{15}$.

13 ITU (2018). Measuring the Information Society Report. URL: https://www.itu.int/en/ITU-D/ Statistics/Documents/publications/misr2018/MISR-2018-Vol-1-E.pdf

${ }^{14}$ ITU (2019). ICT Price Baskets. Available at: https://www.itu.int/net4/itu-d/ipb/

${ }^{15}$ NRI (2020). NRI countries 2020. URL: https://networkreadinessindex.org/nri-2020-countries/ 
Table 1

INDEX OF NETWORK READINESS FOR PARTICULAR COUNTRIES OF THE WORLD IN $2020^{16}$

\begin{tabular}{|l|c|c|c|c|c|c|}
\hline \multicolumn{1}{|c|}{ Country } & Index & Position & Technologies & People & $\begin{array}{c}\text { Government } \\
\text { bodies }\end{array}$ & Influence \\
\hline Sweden & 82.75 & 1 & 83.82 & 78.07 & 88.88 & 80.23 \\
\hline Denmark & 82.19 & 2 & 79.71 & 80.81 & 89.80 & 78.45 \\
\hline Singapore & 81.39 & 3 & 76.16 & 77.86 & 83.35 & 88.17 \\
\hline Netherlands & 81.37 & 4 & 83.81 & 73.45 & 89.47 & 78.75 \\
\hline Switzerland & 80.41 & 5 & 85.67 & 70.02 & 85.04 & 80.93 \\
\hline Finland & 80.16 & 6 & 78.24 & 78.19 & 88.61 & 75.59 \\
\hline Norway & 79.39 & 7 & 75.23 & 73.88 & 91.30 & 77.14 \\
\hline USA & 78.91 & 8 & 82.88 & 74.59 & 86.23 & 71.96 \\
\hline Germany & 77.48 & 9 & 79.18 & 70.54 & 83.52 & 76.69 \\
\hline The United Kingdom & 76.27 & 10 & 78.34 & 69.69 & 82.65 & 74.40 \\
\hline Luxembourg & 75.27 & 11 & 79.28 & 68.35 & 82.06 & 71.39 \\
\hline Australia & 75.09 & 12 & 70.38 & 71.91 & 86.77 & 71.30 \\
\hline Canada & 74.92 & 13 & 73.59 & 68.71 & 85.85 & 71.53 \\
\hline Republic of Korea & 74.60 & 14 & 65.02 & 79.60 & 81.44 & 72.33 \\
\hline Japan & 73.54 & 15 & 65.55 & 76.79 & 77.53 & 74.29 \\
\hline New Zealand & 73.27 & 16 & 68.44 & 69.56 & 86.57 & 68.49 \\
\hline France & 73.18 & 17 & 69.52 & 67.77 & 82.56 & 72.85 \\
\hline Australia & 72.92 & 18 & 70.47 & 69.44 & 80.04 & 71.74 \\
\hline Ireland & 72.13 & 19 & 72.10 & 59.17 & 80.71 & 76.54 \\
\hline Belgium & 70.67 & 20 & 69.26 & 63.80 & 79.57 & 70.05 \\
\hline Iceland & 70.55 & 21 & 72.76 & 67.49 & 73.45 & 68.50 \\
\hline Hong Kong (China) & 70.52 & 22 & 72.84 & 63.76 & 75.55 & 69.94 \\
\hline Estonia & 70.32 & 23 & 63.55 & 67.59 & 84.93 & 65.20 \\
\hline Israel & 69.81 & 24 & 64.38 & 69.14 & 74.60 & 71.12 \\
\hline Spain & 67.31 & 25 & 62.96 & 62.82 & 77.76 & 65.68 \\
\hline Malta & 66.73 & 26 & 61.60 & 60.91 & 73.38 & 71.03 \\
\hline Slovenia & 66.58 & 27 & 60.31 & 62.53 & 75.81 & 67.67 \\
\hline Czech Republic & 66.33 & 28 & 62.90 & 59.30 & 75.92 & 67.22 \\
\hline Lithuania & 64.70 & 29 & 56.10 & 63.97 & 78.87 & 59.86 \\
\hline UAE & 64.42 & 30 & 54.50 & 70.62 & 71.55 & 61.02 \\
\hline & & & & & & \\
\hline
\end{tabular}

${ }^{16}$ Developed by the author based on: NRI (2020). NRI countries 2020. URL: https://networkreadinessindex org/nri-2020-countries/ 
According to the Network Readiness Index, all 134 countries are divided into 4 quartiles. 1st quartile (34 countries) are developed countries and China, Korea, United Arab Emirates (Table 1); 2nd quartile (33 countries) are countries with economies in transition and developing countries; 3rd quartile (34 countries) are also countries with economies in transition and developing countries; 4th quartile (33 countries) are developing countries. Therefore, there is a gap in network readiness between economic groups of countries. Moreover, there must be certain steps in economic policy for the widespread introduction of information technologies in developing countries.

In the context of the COVID-19 pandemic, the use of the prospects of digitalization, informatization, networking and "platformization" of public life made it possible to organize education, meetings, seminars, trainings, etc., as well as work remotely during quarantine.

It is necessary to develop a balanced social strategy with the maximum use of the potential of the economy socialization to minimize the negative impact of digitalization on the social economy model. Thus, the social economy, where all conditions have been created for the realization of the citizens' potential, is based on the development of small and medium-sized businesses. This shows a direct connection between the social economy model and digitalization, as well as this development trend of the social economy model.

\section{Greening of the global economy}

Global trends in social development are in line with most of the UN 2030 Sustainable Development Goals: "no poverty, zero hunger, ensuring peace, justice and strong institutions, promoting sustainable agriculture, ensuring healthy lifestyles and the well-being of people of all ages, ensuring inclusive and equitable quality education and lifelong learning for all, ensuring the availability and sustainable management of water and sanitation, ensuring all people have access to affordable, reliable, sustainable and modern energy sources; promoting continuous, integrated and sustainable economic growth, full and productive employment and decent work for everyone, reducing inequality within and between countries, ensuring openness, security, resilience and environmental sustainability of cities and towns, ensuring the transition to sustainable consumption and production patterns, taking urgent action to combat climate change and its impacts, conserve and sustainably use the oceans, seas and marine resources for sustainable development, protection and restoration of terrestrial ecosystems and promotion of their rational use, sustainable forest management, combating desertification, stopping and reversing the process of land degradation and stopping the loss of biodiversity" ${ }^{\prime \prime}$.

\footnotetext{
${ }^{17}$ Resolution adopted by the General Assembly on 25 September 2015. "Transforming our world: Agenda for sustainable development until 2030". URL: https://www.undp.org/content/dam/ukraine/docs/SDGreports/ Agenda2030_UA.pdf [In Ukrainian].
} 
Greening society and the economy affect the overwhelming majority of sustainable development goals by ensuring the well-being of people of all ages, reducing social inequality, improvement of people's health, rational use of natural resources, protection of the environment for future generations, creation of new jobs in green industries, development of "green" (agricultural) tourism, solving the problem of hunger on an innovative basis, etc. Thus, greening is an important modern trend in the social economy development. If the digitalization of public life in general has positive and negative sides, then greening for the social sphere has more advantages. The social effect of greening for the social development is to help improve the population well-being through the preservation of the environment and the rational use of natural resources. As one of the components of sustainable development, greening the economy affects ensuring social justice and responsibility, preserving health and increasing longevity of people, reducing social inequality and stratification of society, equitable access to limited natural resources ${ }^{18}$.

Greening, as a trend in the social economy development, has not only economic, but also social justification. There are convincing arguments in favour of joining the efforts of the state and the private sector in the framework of greening production activities and other spheres of public life. In this regard, the government faces the challenge of creation of a different conditions for the production of "green" products and services by refusing to provide subsidies to outdated industries, reforming environmental policy and creation of new incentives, strengthening market infrastructure and market mechanisms, redistributing public investment and transitioning to "green" public procurement. Moreover, the private sector is faced with the task of understanding and using the real opportunities provided by the greening of the economy in the "green" sectors, as well as to respond to the reform of environmental policy by increasing funding and investing in "green" investments, supporting "green" projects ${ }^{19}$, which has a positive effect on a social development.

In the social context, the greening of the economy correlates with the development of the health care system and education, with ensuring a high life expectancy and quality of life, with a high level of awareness and responsibility of the population and has a positive effect on the food market.

\section{Post-pandemic development of the global economy}

These days, the latest trend of post-pandemic development enhances both global opportunities and dangers. The global pandemic raised the issue of multivariance and non-obviousness of the solution to the dilemma "human health - economic development and competitiveness", since quarantine

\footnotetext{
${ }^{18}$ Stukalo N. V., Simakhova A. O. "Green" economy: the social aspect ( $u k r$. «Zelena» ekonomika: sotsialnyi aspekt) // "Zelena» ekonomika: vid hlobalnoi kontseptsii do realii mistsevoho rozvytku : kolekt.monohr. / [N. V. Stukalo, ta in.]. D. : Seredniak T.K., 2018. 336 s. S. 69-79. [In Ukrainian].

19 Ibid.
} 
measures led to significant economic losses, bankruptcy, growth of debts in the private sector, as well as the likelihood of a radical redistribution of budgetary allocations in favour of the health sector, medical science and education, a decrease in the mobility of the labour market ${ }^{20}$.

A significant economic recession is predicted in 2021 for all countries of the world community, especially for the countries of the European Union. Only the economy of China will grow as the COVID-19 pandemic began in that country and it remains ahead of the pandemic wave of disease. The pandemic will affect regional social differentiation across the world. Global GDP will reach its pre-pandemic value no earlier than $2022{ }^{21}$.

The pandemic will affect competitiveness at the national and global levels, the development of small businesses, the functioning of the capital market, the quality of life, employment of the population and its form, the medical sphere and the education system, and socialization processes. The COVID-19 pandemic and quarantine have made adjustments in the labour market, as well as in the forms of higher education in almost all universities in the world. The transition to distance learning using modern Internet technologies has been carried out, which has led to certain challenges. The question of high-quality distance learning has also arose. New forms and methods of teaching have become more relevant in conditions of quarantine. Thud, the COVID-19 pandemic has led to changes not only in the global architectonics and the system of the world economy, but also in the transformation of higher education.

The latest trends have impacted rapidly on new requests for the training of specialists. The so-called "soft skills" have become relevant, which allow future employees to adapt to new challenges and allow them to self-learn throughout their lives. Both teachers and students have actively pursued the development of their digital competencies to meet the challenges of the online environment. Distance learning has led to the use of new approaches to the organization of lectures and seminars, home and independent work of students. The potential for the social life technologization has made it possible to minimize the negative consequences of online learning.

The post-pandemic development is likely to be characterized by the following things:

- a large redistribution of markets for goods, services, intellectual property, capital between business entities in favour of those who are less debt-laden, has free capital for the profitable acquisition of new assets ${ }^{22}$;

${ }^{20}$ Simakhova A. O. Models of social economy in the global dimension ( $u k r$. Modeli sotsialnoi ekonomiky u hlobalnomu vymiri): dys.. ... doktora ekonomichnykh nauk : spets. 08.00.02. - K.: 2020, 473 s. [In Ukrainian].

${ }_{21}$ COVID-19 to send almost all G20 countries into a recession, The Economist Intelligence Unit, URL: https://www.eiu.com/n/covid-19-to-send-almost-all-g20-countries-into-a-recession/

${ }^{22}$ Halasiuk V. Great Deleveraging. What will happen to the economy after the coronavirus ( $u k r$. Velykyi deleveridzh. Shcho bude z ekonomikoiu pislia koronavirusu). URL: https://nv.ua/ukr/biz/experts/globalnaekonomika-pislya-pandemiji-koronavirusu-shcho-bude-i-chim-vse-zakinchitsya-viktor-galasyuk-50080230.html (дата звернення: 08.04.2020). [In Ukrainian]. 
- deepening social inequality between country and country-wide;

- an increase in the role and degree of state intervention in social and economic processes;

- deepening the impact of the negative consequences of global problems and challenges for countries with economies in transition and developing economies.

In our opinion, the favourableness of the post-pandemic period for the socialization of the economies of the countries all over the world will consist in the following: an increase in budgetary support for the development of the social sphere and assistance to citizens; strengthening the financial base for the development of medicine; networking and platformization of the economy; rapid development of small and mediumsized businesses; development of non-traditional employment forms. This will help to overcome the crisis caused by the pandemic and increase household income.

\section{Directions for enhancing the positive effect of global development trends on the social economy}

Using the possibilities of the world economy transnationalization for the development of the social economy is of great importance. TNCs, as global actors of influence on the processes of socialization, can create new jobs for countries, develop social infrastructure, implement social projects and generally improve the well-being of the population of these countries. TNCs, shaping the social culture of their employees, influence on the social mentality and consciousness of the people of a particular country. The potential for transnationalization of the global economy must be attracted and used by governments to solve and minimize the negative impact of social problems at the global level.

Modern global trends of regionalization and institutionalization of economic development for the development of the social economy have opportunities to strengthen international social cooperation and effectively involve countries in social, regional groupings, as well as institutions. At the global level, various countries participate in the creation and an approval of international social standards, rules, norms, allows for social reforms and the transition to another more effective social development.

Inclusiveness, as the latest trend in the development of the social economy is aimed at levelling imbalances and disproportions in social, economic, gender, environmental and other aspects. The potential of this global trend for countries can be used to reform the labour market, create new jobs for women, elderly, youth, refugees, etc., and create an equal career development opportunities. 
The potential for greening the economy can be primarily used for the development of ecological and / or organic farming, agriculture (production of safe and organic products, care for the environment, as well as own business to form the basis for self-sufficiency and self-employment of the population). Greening agriculture, especially private farmers, will serve to reduce poverty and the flow of "green" investments in this area, as well as to develop the market for organic food. Given this, it is important to develop organic farming as a private initiative aimed at development of the greening society and preserving the environment. At the same time, this will ensure an increase in the quality and standard of the population living, as well as an increase in the amount of food in the context of the existing global food problem ${ }^{23}$.

In addition to the development of ecological farming and "green" cities, two main directions for improvement of the well-being of the population are the development of "green" tourism, which also contributes to the inflow of foreign investment and the transition to alternative energy sources, will significantly reduce the population's expenses on energy resources, thereby increasing the level of people's lives ${ }^{24}$.

The directions for enhancing the positive effect of the economy digitalization for the country's social sphere and ensuring the well-being of people are ${ }^{25}$ :

- expanding the range of goods and services;

- increasing the availability of goods and services from different countries for ordinary citizens by using the Internet;

- development of technologies in the medical field, contributes to the treatment of deadly diseases;

- appearance of new professions;

- greater mobility and flexibility of the education system (higher and vocational);

- opportunity to work and study remotely and outside of your region of residence;

- using scientific developments to improve the environmental situation in the country;

- increase in life expectancy;

- creation of "smart" cities and enterprises;

- development of block chain technologies and their use in the social sphere;

${ }^{23}$ Simakhova A. O. Models of social economy in the global dimension ( $u k r$. Modeli sotsialnoi ekonomiky u hlobalnomu vymiri): dys.. ... doktora ekonomichnykh nauk : spets. 08.00.02. — K.: 2020, 473 s. [In Ukrainian].

${ }^{24}$ Stukalo N. V., Simakhova A. O. "Green" economy: the social aspect (ukr. «Zelena» ekonomika: sotsialnyi aspekt) // "Zelena» ekonomika: vid hlobalnoi kontseptsii do realii mistsevoho rozvytku : kolekt.monohr. / [N. V. Stukalo, ta in.]. D. : Seredniak T.K., 2018. 336 s. S. 69-79. [In Ukrainian].

${ }_{25}$ Simakhova A. O. Social prospects for the development of science and digital economy in Ukraine ( $u k r$. Sotsialni perspektyvy rozvytku nauky ta tsyfrovoi ekonomiky v Ukraini), Sotsialna ekonomika, 2018. Vyp. 56. S. 216-221. [In Ukrainian]. 
- actualization of the system of social values through the virtual space;

- formation of a culture of social responsibility and social partnership in the Internet space.

\section{Conclusions}

Therefore, it can be said that digitalization, innovatization, intellectualization, informatization and greening of society, as the latest trends in the development of the social economy, as well as transnationalization, regionalization and institutionalization, enhance its potential in the global aspect. From this perspective, the activization of global actors in the development of social economy models (in particular, TNCs, international organizations, influential media, famous personalities, communities of experts, etc.), the creation of global social rules and norms, the development of intellectual potential, information support of social processes, investment in information, "green" and digital technologies, the creation of appropriate new jobs are also important areas for realizing the potential and development of the social economy in global conditions. All global trends in the development of the social economy are interconnected and interdependent.

The development of Industries 4.0 and 5.0 with the growing influence of digitalization, from a social point of view, contributes to the expansion of consumption and an increase in the level and quality of life of the population. It has a positive effect on the social economy development and the electronic government system via the use of block chain technologies (E-government), which makes it easier for the population to access public authorities, social services, request public information, certificates and other documentation. Due to the active development of social networks, digital technologies affect the social sphere, values and culture of society, and form digital consciousness among the population.

Due to the potential of digitalization and informatization of public life in most countries of the world, it was possible to avoid an economic collapse during quarantine by organizing training and work of employees remotely. It is the latest global trends that point to the need to acquire online skills and adapt to the new global environment.

The potential of using the latest global trends for the development of the social economy lies in the consolidation of efforts to socialize the economies of the countries of the world; unification of global social standards and deepening of international social cooperation; promotion of the development of non-traditional employment forms; strengthening advisory and expert activities in the social sphere for the countries all over the world and other global actors; development of block chain technologies in the social sphere, "smart" cities and enterprises. 


\section{References}

1. COVID-19 to send almost all G20 countries into a recession, The Economist Intelligence Unit, URL: https: / / www.eiu.com / $\mathrm{n} /$ covid-19-to-send-almost-allg20-countries-into-a-recession /

2. ITU (2018). Measuring the Information Society Report. Available at: https: / /www.itu.int/en /ITU-D / Statistics / Documents / publications / misr2018/MISR-2018-Vol-1-E.pdf

3. ITU (2019). ICT Price Baskets. Available at: https://www.itu.int/ net4/itu-d/ipb/

4. Kalenyuk I., Dyakon A. Modern trends in the development of education in a global context; Strategic priorities for developing Ukraine and Georgia: innovation and partnership: [monograph] / under ed. D. G. Lukianenko and T. Beridze. Batumi, 2018. 308 p. (P. 224-244).

5. Kolot A., Herasymenko O. Digital transformation and new business models as determinants of formation of the economy of nontypical employment. Social and labour relations: theory and practice, 2020, 10(1), 33-54. doi:10.21511/slrtp.10(1).2020.06

6. Menshikov V., Lavrinenko O., Sinica L., Simakhova A. Network capital phenomenon and its posibilities under the influence of development of information and communication technologies, Journal of Security and Sustainability Issues 2017, 6(4), 585-604 doi: http://doi.org/10.9770/issi.2017.6.4.(5).

7. NRI (2020). NRI countries 2020. Available at: https:// networkreadinessindex. org / nri-2020-countries /

8. Halasiuk, V. (2020) Great deleveraging. What will happen to the economy after the Coronavirus. Retrieved from https://nv.ua/ukr/biz/experts / globalna-ekonomika-pislya-pandemiji-koronavirusu-shcho-bude-i-chim-vsezakinchitsya-viktor-galasyuk-50080230.html [In Ukrainian].

9. Poruchnyk A. M. Stoliarchuk Ya. M. Hlobalni imperatyvy transnatsionalizatsii natsionalnykh ekonomik. Formuvannia rynkovoi ekonomiky : zb. nauk. pr. Kyiv : KNEU, 2009. Vyp. 21. 257-278. - S.257. [In Ukrainian].

10. Rezoliutsiia, pryiniata Heneralnoiu Asambleieiu 25 veresnia $2015 \mathrm{r}$. «Peretvorennia nashoho svitu: Poriadok dennyi u sferi staloho rozvytku do 20230 roku». URL: https:/ / www.undp.org/content/dam/ukraine/docs/SDGreports / Agenda2030_UA.pdf [In Ukrainian].

11. Resursy ta modeli hlobalnoho ekonomichnoho rozvytku: monohrafiia, za zah. red. Lukianenka D.H., Poruchnyka A.M. K.: KNEU, 2011. 703 s. [In Ukrainian].

12. Simakhova $A$. O. Modeli sotsialnoi ekonomiky u hlobalnomu vymiri: dys.. ... doktora ekonomichnykh nauk : spets. 08.00.02. - K.: 2020, 473 s. [In Ukrainian].

13. Simakhova $A$. O. Sotsialni perspektyvy rozvytku nauky ta tsyfrovoi ekonomiky v Ukraini, Sotsialna ekonomika, 2018. Vyp. 56. S. 216-221. [In Ukrainian].

14. Stukalo N.V., Simakhova A. O. «Zelena» ekonomika: sotsialnyi aspekt / / «Zelena» ekonomika: vid hlobalnoi kontseptsii do realii mistsevoho rozvytku : kolekt.monohr. / [N. V. Stukalo, ta in.]. D. : Seredniak T.K., 2018. 336 s. S. 6979. [In Ukrainian].

The article was received by the Editorial Board on March 03, 2021. 